\title{
ESTIMASI TINGKAT RISIKO INVESTASI EMAS MENGGUNAKAN PENDEKATAN GENERALIZED EXTREME VALUE DAN GENERALIZED PARETO DISTRIBUTION
}

\author{
Noviana Pratiwi ${ }^{1}$, Catur Iswahyudi ${ }^{2}$ \\ ${ }^{1}$ Jurusan Statistika, IST AKPRIND Yogyakarta \\ ${ }^{2} J$ urusan Teknik Informatika, IST AKPRIND Yogyakarta \\ Email : ${ }^{1}$ novianapratiwi@akprind.ac.id
}

\begin{abstract}
This study estimates the level of risk in investing in gold. Value at Risk (VaR) is a method which can be used for calculating the level of risk. There are two distribution approaches used, namely Generalized Extreme Value Distribution (GEV) and Generalized Distribution Pareto (GDP). These two distributions are used because gold data is alleged to have a heavy tail distribution. The study uses secondary data on gold prices with January 2015 to December 2017 period with a total of 876 data. The results obtained indicate that the data return for the gold price has a heavy tail. Estimation results obtained indicate that the VaR value at the $95 \%$ confidence level is less than VaR with a 99\% confidence level so it can be concluded that the higher the level of risk to be taken, the greater the level of confidence and capital allocation to cover losses taken by investors. The GDP Estimation value gives a greater value than GEV. and the largest $\mathrm{VaR}$ value is shown at $4.049 \%$, which means that the maximum loss that may occur in one period ahead is $4.049 \%$.
\end{abstract}

Keywords: Value at Risk (VaR), Extreme Value Theory (EVT), Generalized Extreme Value (GEV), Generalized Distribution Pareto (GDP)

\begin{abstract}
Abstrak. Penelitian ini melakukan estimasi tingkat risiko dalam melakukan investasi emas. Metode untuk menghitung tingkat risiko yang digunakan adalah Value at Risk (VaR). Ada dua pendekatan dsitribusi yang digunakan yaitu Generalized Extreme Value Distribution (GEV) dan Generalized Distribution Pareto (GDP). Dua distribusi ini digunakan karena data emas diduga memiliki ekor berdistribusi gemuk (heavy tail). Penelitian menggunakan data sekunder harga emas dengan periode 2 Januari 2015 sampai Desember 2017 dengan total 876 data. Hasil yang diperoleh menunjukkan bahwa data return harga emas memiliki ekor gemuk (heavy tail). Hasil estimasi yang diperoleh menunjukkan bahwa nilai VaR pada tingkat kepercayaan 95\% kurang dari VaR dengan tingkat kepercayaan 99\% sehingga dapat disimpulkan bahwa semakin tinggi tingkat risiko yang akan diambil maka semakin besar juga tingkat konfidensi dan alokasi modal untuk menutupi kerugian yang diambil oleh investor. Nilai Estimasi GDP memberikan nilai lebih besar daripada GEV. dan nilai VaR terbesar ditunjukkan sebesar 4,049\% yang berarti kerugian maksimum yang mungkin terjadi pada satu periode kedepan sebesar $4,049 \%$ dari total investasi
\end{abstract}

Kata kunci: Value at Risk (VaR), Extreme Value Theory (EVT), Generalized Extreme Value (GEV), Generalized Distribution Pareto (GDP) 
JOURNAL OF FUNDAMENTAL MATHEMATICS AND APPLICATIONS (JFMA) VOL. 2 NO. 1 (Jun 2019)

Available online at www.jfma.math.fsm.undip.ac.id

\section{PENDAHULUAN}

Harga emas di Indonesia dari tahun 1994 sampai 1997 cenderung tidak mengalami pergerakan. Namun setelah 1997 harga emas mulai menanjak naik sampai 2015 meskipun dalam perjalanannya harga emas mengalami naik turun secara fluktuatif namun dalam jangka panjang harga emas cenderung naik. Penelitian tentang emas banyak dilakukan oleh peneliti di Indoneia maupun di dunia.[1] pernah meneliti tentang bagaimana kinerja emas dibanding instrumen investasi yang lain, hasilnya adalah emas merupakan instrumen investasi yang aman pada saat instrumen investasi keuangan lain mengalami peningkatan. [2] membahas tentang investasi dalam instrumen emas diliai lebih menguntungkan dibandingkan dengan berinvestasi dalam saham perusahaan pertambangan emas dalam kurun waktu sebelas tahun.

Euforia emas yang semakin menjadi target investasi di masyarakat harus dibarengi oleh sikap hti-hati dari masyarakat. Direktur Bisnis II PT Pegadaian (Persero), Wasis Djuhar, pada 10 april 2013 mengatakan bahwa dibalik manfaat dan keuntungannya, ternyata investasi emas mengandung risiko. Banyak risiko dalam berinvestasi dalam emas, diantaranya adalah mendapat emas palsu, potensi kehilangan maupun tindak kejahatan yang terjadi dan fluktuasi harga turun. Volatilitas pergerakan harga emas ini yang menjadi munculnya risiko pasar. [3] berpendapat bahwa untuk mengontrol dan mengurangi risiko investasi yang terjadi, para pelaku investasi dapat melakukan pengukuran volatilitas atau tingkat risiko dari aset aset yang dimiliki. Ukuran resiko yang dicari ini nantinya digunakan untuk mengendalikan atau mengelola risiko dalam manajemen risiko. Ukuran risiko yang paling populer digunakan oleh beberapa pelaku investasi adalah Value at Risk (VaR).

Value at Risk (VaR) merupakan salah satu alat atau teknik untuk mengetahui kerugian terburuk yang mungkin terjadi sebagai akibat dari kepemilikan suatu instrumen investasi atau portofolio selama periode waktu tertentu, dengan tingkat spesifikasi tertentu yang dikenal sebagai tingkat kepercayaan (confidence level). Berdasarkan pertanyaan tersebut, dapat dilihat adanya tiga variabel yang penting yaitu besar kerugian, periode waktu dan besar tingkat kepercayaan [4].

Penentuan metode yang tidak tepat akan membuat perhitungan Value at Risk tidak akurat. Misalnya metode standar dalam Value at Risk seperti varian kovarian atau simulasi historis akan menyebabkan ketidaktepatan distribusi return nya yang berakibat pada tidak akuratnya nilai Value at Risk yang dihasilkan [5] Teori nilai ekstrim diakui menjadi metode yang tepat untuk mencari Value at Risk dalam kondisi ekstrem. [5] menyebutkan bahwa jika terjadi kondisi ektrim, maka Risk Metrics Technique tidak bisa menghitung VaR secara akurat. [6] membahas hubungan antara estimasi ekor, kondisi ektrim dan perhitungan VaR, beliau menyebutkan bahwa teori nilai ekstrim secara statistik lebih natural sehingga menghasilkan pendekatan yang kuat dalam perhitungan $\mathrm{VaR}$. Estimasi VaR dengan pendekatan Extreme Value juga pernah diteliti oleh [7].

Dalam Extreem Value Theory (EVT) terdapat dua pendekatan yang sering digunakan yaitu pendekatan yang pertama adalah Generalized Extreme Value (GEV). Dimana inti dari distribusi GEV adalah mengidentifikasikan nilai ekstrem berdasarkan nilai maksimal. Sedangkan pendekatan yang kedua adalah Generalized Distribution Pareto (GDP) dimana dalam distribusi ini mengidentifikasi nilai ekstrem dengan nilai ambang. Diperkirakan Kondisi Ekstrem pada Investasi emas di Indonesia bida didekati dengan dua distribusi ini. Untuk itu 
akan dicari metode mana yang paling akurat dari kedua distribusi tersebut untuk menghitung tingkat risiko dari investasi emas di Indonesia

\section{KAJIAN LITERATUR}

\subsection{Teori Nilai Ekstrim}

Teori nilai ekstrim diperkenalkan pertama kali oleh Fisher, Tippet dan Gnedenko (19201940) dan Gumbel (1920). Nilai Ekstrim Teori adalah salah satu teori yang mebahas tentang kondisi-kondisi ekstrim yang membentuk fungsi sebaran pada nilai tersebut. Teori nilai Ekstrim memiliki dua distribusi yaitu distribusi generalized extreme value dan distribusi Generalized Pareto.

\subsection{Distribusi Generalized Extreme Value (GEV)}

Inti dari distribusi GEV adalah data dibagi dalam blok-blok dalam periode waktu tertentu. Tiap blok periode ditentukan besarnya data yang paling maksimal.

Misal ada himpunan $\mathrm{n}$ return $\left\{r_{1}, r_{2}, \ldots, r_{n}\right\}$. Return minimum dari himpunan adalah $r_{(1)}=$ $\min _{1 \leq j \leq n}\left\{r_{j}\right\}$, dan nilai maksimum adalah $r_{(n)}=\max _{1 \leq j \leq n}\left\{r_{j}\right\}$. Menurut [8] nilai ektrim difokuskan pada nilai minimum karena nilai minimum sangat relevan dengan perhitungan $\mathrm{VaR}$.

Asumsikan return $r_{t}$ barisan saling bebas dengan fungsi distribusi komulatif $F(x)$ dengan rentang return adalah $[l, u]$. Untuk $\log$ return $l=-\infty$ dan $u=\infty$, fungsi distribusi komulatif $r_{(1)}$ dinyatakan sebagai $F_{n, l}(x)$, yaitu :

$$
\begin{aligned}
F_{n, 1}(x)=\operatorname{Pr}\left[r_{(l)} \leq x\right] & =1-\operatorname{Pr}\left[r_{(l)}>x\right]=1-\operatorname{Pr}\left(r_{1}>x, r_{2}>x, \ldots, r_{n}>x\right) \\
& =1-\prod_{j=1}^{n} \operatorname{Pr}\left(r_{j}>x\right) \\
& =1-\prod_{j=1}^{n}\left[1-\operatorname{Pr}\left(r_{j} \leq x\right)\right] \\
& =1-\prod_{j=1}^{n}[1-F(x)] \\
& =1-[1-F(x)]^{n} .
\end{aligned}
$$

Dalam prakteknya, fungsi distribusi komulatif $\mathrm{F}(\mathrm{x})$ dari $r_{(1)}$ tidak diketahui, maka oleh sebab itu $F_{n, 1}(x)$ didefinisikan menjadi $F_{n, 1}(x) \rightarrow 0$ jika $x \leq 1$ dan $F_{n, 1}(x) \rightarrow 1$ jika $x>1$.

Teori extreme value memiliki dua parameter $\left\{\beta_{n}\right\}$ dan $\left\{\alpha_{n}\right\}$ dengan $\alpha_{n}>0$ berdistribusi $r_{\left(l^{*}\right)}=\frac{r_{(1)}-\beta_{(n)}}{\alpha_{n}}$ konvergen pada distribusi nongenerated dengan $\mathrm{n}$ menuju tak hingga. Barisan $\left\{\beta_{n}\right\}$ faktor lokasi dan $\left\{\alpha_{n}\right\}$ faktor skala. Berdasarkan pada asumsi, distribusi batas dinormalkan minimum $r_{\left(l^{*}\right)}$ adalah

$$
F *(x)=\left\{\begin{array}{lr}
1-\exp \left[-(1+k x)^{\frac{1}{k}}\right] & \text { jika } k \neq 0 \\
1-\exp [-\exp (x)] & \text { jika } k=0
\end{array}\right.
$$


untuk $x<-1 / k$ jika $k<0$ dan $x>-1 / k$ jika $k>0$ dimana tanda * menyatakan minimum. Parameter k menyatakn shape parameter yang memenuhi prilaku tail distribusi batas dan $\alpha=$ $-1 / k$ disebut tail indeks dari distribusi statistik ekstrim [9].

Persamaan (2.2) disebut distribusi general extreme value (GEV) oleh Jenkison (1955) dalam [7] untuk minimum. Fungsi densitas probabilitas (pdf) dari persamaan (2.2) dapat diperoleh persamaan deferensialnya menjadi

$$
f *(x)=\left\{\begin{array}{rr}
(1+k x)^{\frac{1}{k}-1} \exp \left[-(1+k x)^{1 / k}\right] \text { jika } k \neq 0 \\
\exp [x-\exp (x)] & \text { jika } k=0
\end{array}\right.
$$

dimana $-\infty<x<\infty$ untuk $k=0$,

$$
\begin{aligned}
& x<-1 \text { untuk } k<0, \text { dan } \\
& x>-1 / k \text { untuk } k>0 .
\end{aligned}
$$

Estimasi parameter model extrime value akan menggunakan metode maksimum likelihood. Asumsikan bahwa sub-periode minimum $\left\{r_{n, i}\right\}$ terdistribusi extreme value sehingga pdf dari $x_{i}=\left(r_{n, i}-\beta_{n}\right) / \alpha_{n}$ diberikan persamaan (2.3) dapat dtetapkan oleh transformasi berikut

$$
f\left(r_{n, i}\right)=\left\{\begin{array}{lr}
\frac{1}{\alpha_{n}}\left(1+\frac{k_{n}\left(r_{n, i}-\beta_{n}\right)}{\alpha_{n}}\right)^{\frac{1}{k}-1} \exp \left[-\left(1+\frac{k_{n}\left(r_{n, i}-\beta_{n}\right)}{\alpha_{n}}\right)^{\frac{1}{k}}\right] & \text { jika } k \neq 0 \\
\frac{1}{\alpha_{n}} \exp \left[\frac{r_{n, i}-\beta_{n}}{\alpha_{n}}-\exp \left(\frac{r_{n, i}-\beta_{n}}{\alpha_{n}}\right)\right] & \text { jika } k=0 .
\end{array}\right.
$$

Fungsi likelihood dari sub-periode minimum adalah

$$
L\left(r_{n, 1}, \ldots, r_{n, g} \mid k_{n}, \alpha_{n} \beta_{n}\right)=\prod_{i=1}^{g} f\left(r_{n, i}\right)
$$

\subsection{Pendekatan GEV pada VaR}

Log-likelihood dari persamaan (2.5) dengan kondisi $k \neq 0$ adalah sebagai berikut

$$
\ln L=-g \ln \alpha_{n}-\left(1+\frac{1}{k}\right) \sum_{i=1}^{g} \ln \left\{1+\frac{k_{n}\left(r_{n, i}-\beta_{n}\right)}{\alpha_{n}}\right\}-\sum_{i=1}^{g}\left\{\left(1+\frac{k_{n}\left(r_{n, i}-\beta_{n}\right)}{\alpha_{n}}\right)^{\frac{1}{k}}\right\} .
$$

Metode maksimal likelihood digunakan untuk mencari VaR, menurut [9] VaR pada probabilitas lebih kecil dari $\mathrm{p}$ adalah

$$
\operatorname{VaR}=\beta_{n}-\frac{\alpha_{n}}{k_{n}}\left\{1-[-n \ln (1-p)]^{k_{n}}\right\}
$$

\subsection{Peak Over threshold atau Distribusi Generalized Pareto}

Metode POT merupakan metode Ekstreme Value teory yang mengidentifikasi nilai ekstrim dengan menggunakan patokan atau threshold [10]. Dalam metode ini akan ditenentukan nilai patokan (maksimal atau minimal) atau threshold. Semua data yang melewati threshold adalah data ekstrim. Semakin tinggi nilai threshold maka distribusinya akan mengikuti Generalized Distribution Pareto (GDP). Fungsi densitas komulatif (CDF) dari GDP adalah 


$$
H_{\xi, \tau(h)}(x)=\left\{\begin{array}{l}
1-\exp \left(-\frac{x}{\tau(h)}\right), \xi=0 \\
1-\left(1+\frac{\xi_{x}}{\tau(h)}\right)^{-\frac{1}{\xi}}, \xi \neq 0
\end{array}\right.
$$

dimana $x>0$ untuk $\xi>0$ dan $0 \leq x \leq \tau(h)$ untuk $\xi<0$. Dan $X_{1}, X_{2}, \ldots, X_{k}$ merupakan nilai ektrim yang melewati threshold $h$.

\subsection{Pendekatan GDP pada VaR}

Dalam pencarian VaR dengan pendekatan GDP, VaR merupakan q\% kuantil dari distribusi nilai total loss[6]. Persamaan umum dari VaR adalah

$$
\operatorname{VaR}_{q \%}=F^{-1}(q \%)
$$

dengan $\mathrm{F}$ adalah fungsi distribudi komulatif (CDF) dari nilai total loss, $F(x)$ adalah distribusi nilai total loss x dan u merupakan nilai threshold maka Excess Over Threshold yang positif mempunyai distribusi sebagai berikut [10]:

$$
F_{u}(y)=\frac{F(y+u)-F(u)}{1-F(u)} .
$$

Untuk threshold yang sangat besar maka $F(u)$ akan mendekati $\left(n-N_{u}\right) / n$ dengan $\mathrm{n}$ merupakan banyaknya data yang berada diatas threshold, sehingga persamaan (2.11) menjadi

$$
F(x)=1-\frac{N_{u}}{n}\left(1+\xi \frac{x-u}{\beta}\right)^{-\frac{1}{\xi}}
$$

dengan $q>F(u)$ maka perhitungan VaR diperoleh dengan melakukan invers terhadap persamaan (2.11) dan diperoleh hasil [11] menjadi

$$
\operatorname{VaR}_{G D P}=u+\frac{\widehat{\beta}}{\xi}\left(\left(\frac{n}{N u}(1-q)\right)^{-\xi}-1\right) .
$$

\section{METODOLOGI}

Dalam melakukan estimasi Value at Risk dengan pendekatan Generalized Extreme Value $(G E V)$ dan Generalized Pareto Distribution maka langkah-langkah yang dilakukan adalah sebagai berikut :

i. Melakukan analisis deskriptif

ii. Diagnosis Extreme Value Theory

iii. Menentukan Estimasi Parameter Generalized Extreme Value (GEV)

a. Menentukan blokmaxima

b. Mengestimasi parameter berdasarkan blok dengan MLE

iv. Menentukan Estimasi Parameter Generalized Pareto Distribution (GDP)

a. Menentukan threshold

b. Menentukan estimasi parameter shape dan skala dengan MLE

v. Mengestimasi VaR dengan parameter GEV dan GPD

vi. Intrepetasi hasil 


\section{HASIL DAN DISKUSI}

Perhitungan Value at Risk pada return dari harga emas menjadi tujuan dalam makalah ini. Harga emas di download secara harian dari situs http://harga-emas.com dari 2 Januari 2015 sampai 31 Desember 2017 dengan total 875 data.

\subsection{Analisis Deskriptif}

Data yang digunakan adalah return dari saham harian yang berjumlah 875 . Tabel 1 dibawah menunjukkan statistika deskriptif dari return harga emas. Statistika deskriptif dari return emas yang digunakan antara lain nilai rata-rata, nilai standar deviasi, nilai maksimum, nilai minimum, jumlah data observasi, nilai skewnes dan nilai kurtosis.

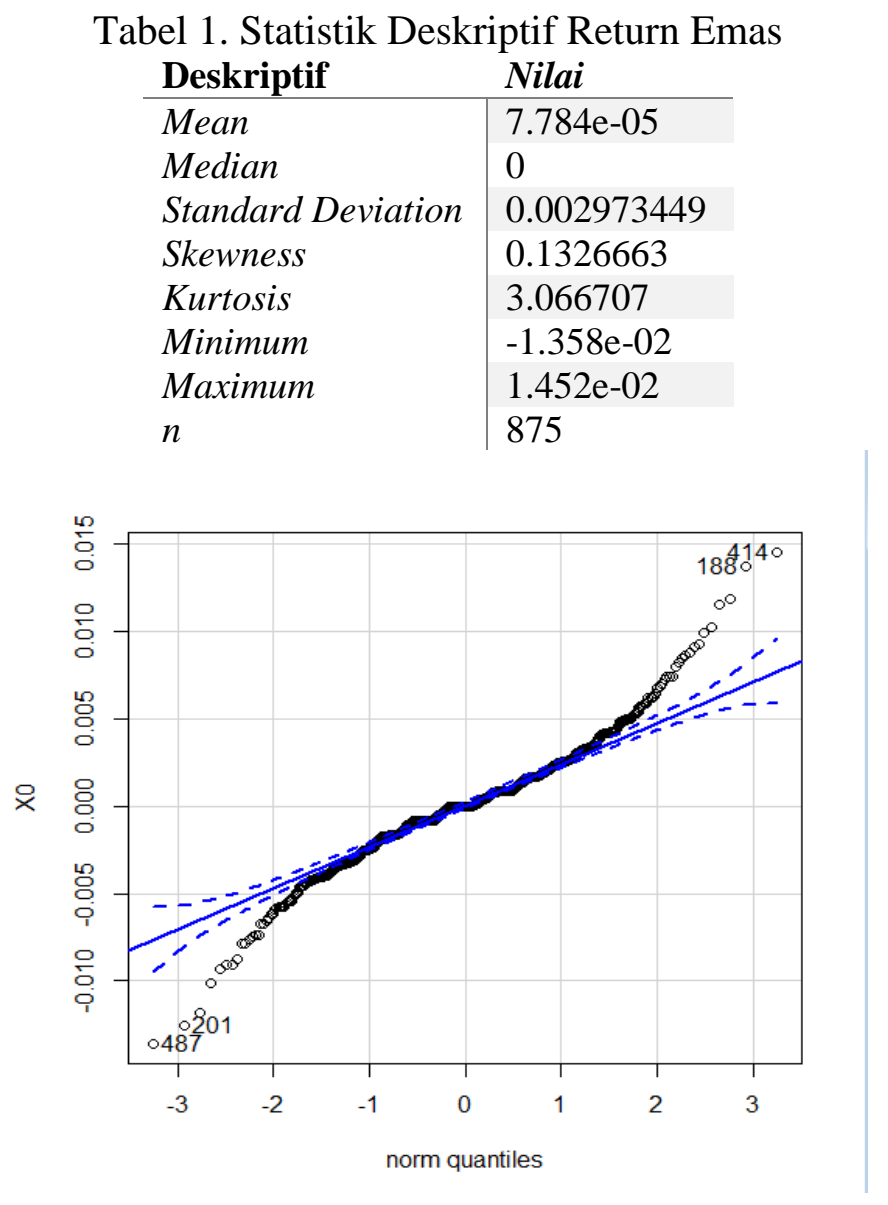

Gambar 1. Q-Q Plot dari return harga emas

Dari Tabel 1 diatas dapat diketahui bahwa nilai rata-rata return harga emas adalah $7.784 \mathrm{e}-$ 05 dengan median nol dan standar deviasi 0.002973449. Nilai skewness dari return emas bernilai positif yaitu 0.1326663 yang artinya bahwa data mengindikasikan berdistribusi return mempunyai ekor kanan yang panjang. Untuk nilai kurtosis dari return emas bernilai cukup tinggi lebih dari tiga yaitu 3.066707. Hal ini berarti data return emas masuk dalam tipe kurtosis Leptokurtic, yaitu bagian tengah distribusi data memiliki puncak yang lebih runcing. Jadi dapat dikatakan bahwa return harga emas memiliki sifat - sifat data finansial yaitu pola Leptokurtic dan volatilitas. Volatilitas dilihat berdasarkan range atau jarak nilai maksimum dan minimum yang relatif cukup jauh, sehingga dapat dikatakan harga emas mengalami fluktuasi pada 
harganya. Dari kurtosis dan skewness, diindikasikan data memiliki distribusi ekor gemuk (heavy tail). Selain itu dapat juga dilihat menggunakan Q-Q Plot seperti pada Gambar 1. Pada Gambar 1 yaitu Normal Q-Q Plot dapat dikatakan bahwa data tidak berada dalam satu garis lurus. Artinya data tidak memiliki distribusi yang sama dengan distribusi pembanding yaitu normal atau dikatakan data tidak mengikuti distribusi normal. Dari gambar 1 juga terlihat bahwa pola data memiliki pola "S" yaitu turun pada bagian kiri dan naik pada bagian kanan, maka dapat dikatakan distribusi data tersebut besifat lebih heavy tail dibandingkan distribusi normal. Selanjutnya untuk melihat nilai ekstrim dari return harga emas dapat digunakan boxplot seperti pada Gambar 2.

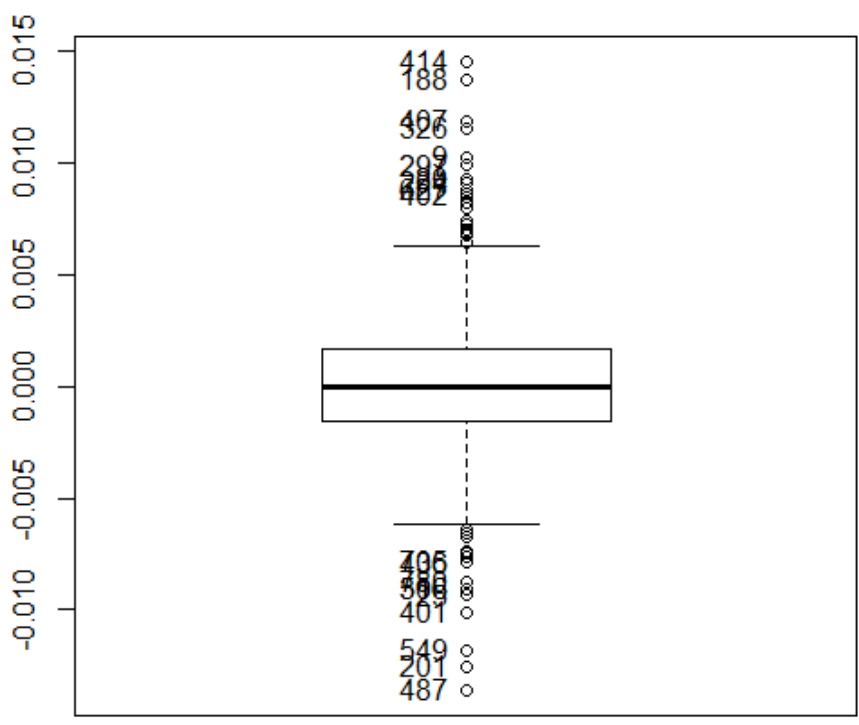

Gambar 2 Boxplot Return Emas

Berdasarkan Gambar 2 dapat dilihat bahwa data return harga emas memiliki sejumlah nilai diluar jangkauan maksimum dan minimum atau outlier serta memiliki nilai ekstrim yang dapat dikatakan jauh dari nilai maksimum atau minimumnya.

\subsection{Generalized Extreme Value (GEV)}

Analisis data berupa pengujian efek GEV pada data perlu dilakukan agar pendekatan yang dilakukan dalam menentukan Value at Risk benar - benar telah menggambarkan bentuk distribusi data. Pengujian tersebut dilakukan dengan beberapa tahap yaitu menentukan nilai maksimum dengan metode block maxima dan selanjutnya mengestimasi parameter dari distribusi GEV sampai didapatkan estimasi parameter yang akan digunakan untuk perhitungan VaR.

\subsection{Menentukan nilai maksimum dengan Blok Maxima}

Pemilihan nilai maksimum dari data dalam studi kasus ini adalah menggunakan block maxima yaitu dengan mengidentifikasi nilai ekstrim berdasarkan nilai maksimum dari data observasi berdasarkan periode tertentu. Pemilihan blok pada penelitian ini yaitu menggunakan blok mingguan dan bulanan. Blok yang dibentuk selama periode mingguan atau dengan 5 hari kerja sebanyak 175 blok, sedangkan untuk blok yang dibentuk selama periode bulanan atau 
dengan 21 hari kerja sebanyak 43 blok. Nilai maksimum dari tiap blok mingguan dapat dilihat pada Gambar 3.
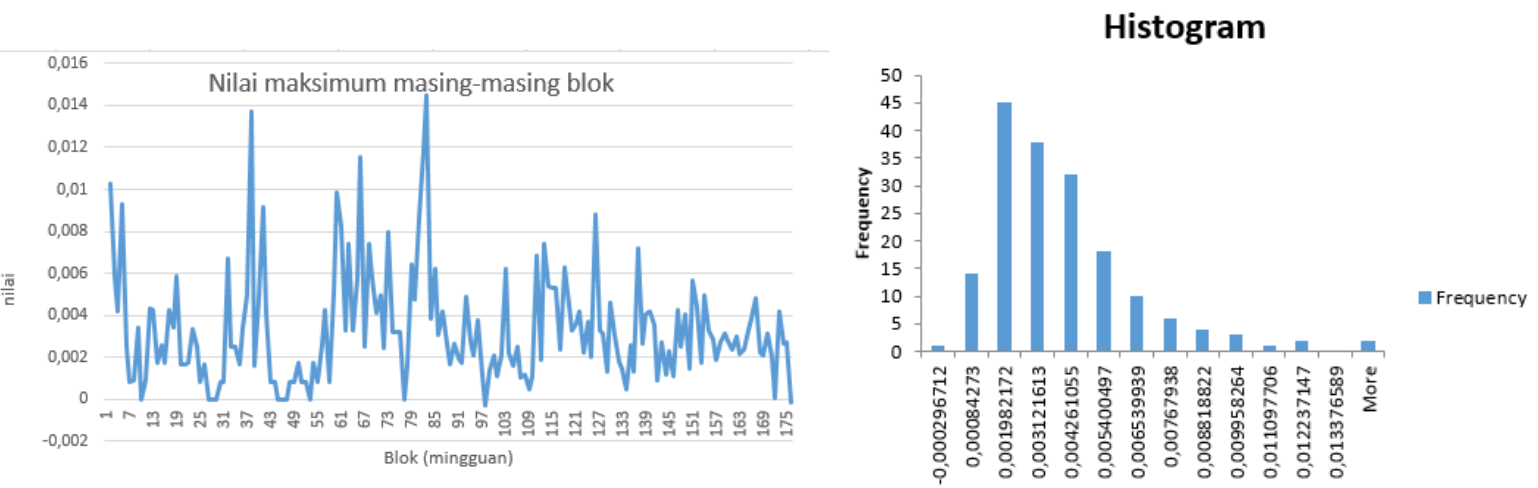

Gambar 3. Nilai Maksimum dan histogram masing-masing blok pada blok mingguan

Gambar 3 menjelaskan nilai maksimum dan Histogram dari setiap bloknya untuk blok mingguan. Nilai maksimum tersebut dihitung hingga pada blok 175. Berdasarkan nilai maksimum tersebut, dapat dilihat bahwa return dari harga emas mengalami fluktuasi dilihat dari urutan nilai maksimum yang berubah - ubah. Dan histogram tidak mendekati distribusi normal karena mempunyai ekor gemuk ke kanan (heavy tail). Jadi dapat disimpulkan bahwa block maxima dari return emas mendekati distribusi Generalized Extreme Value.

Untuk return maksimum masing masing blok bulanan 21 hari kerja dilakukan langkah yang sama dan didapat hasil seperti pada Gambar 4.
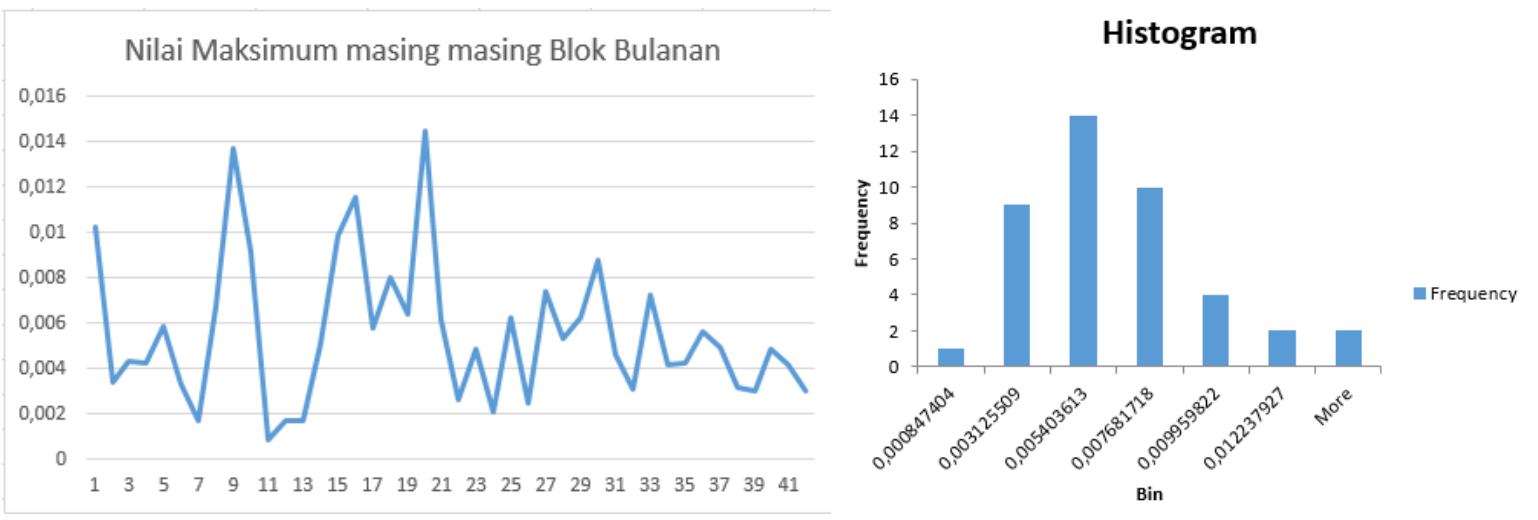

Gambar 4. Nilai Maksimum dan histogram masing-masing blok pada blok Bulanan

Analog dengan blok mingguan, Gambar 4 menjelaskan nilai maksimum dari setiap bloknya untuk blok bulanan. Nilai maksimum tersebut dihitung hingga pada blok 42 . Berdasarkan nilai maksimum tersebut, dapat dilihat bahwa return dari harga emas mengalami fluktuasi dilihat dari urutan nilai maksimum yang berubah - ubah. histogram tidak mendekati distribusi normal karena mempunyai ekor gemuk ke kanan (heavy tail). Jadi dapat disimpulkan bahwa block maxima dari return emas mendekati distribusi Generalized Extreme Value.

\subsection{Menentukan Estimasi Parmeter GEV}

Setelah menetukan nilai maksimum dengan metode blok maxima bahwa sampel data ekstrim didapatkan 175 data estrim dengan blok mingguan dan 42 data ekstrim dengan blok 
bulanan. Maka langkah selanjutnya dalam mencari estimasi parameter GEV menggunakan Maximum Likelihood. Hasil Parameter tersaji pada Tabel 2.

Tabel 2. Estimasi GEV pada Blok Mingguan dan Bulanan

\begin{tabular}{r|ll} 
Parameters & $\begin{array}{l}\text { Weekly } \\
(175 \\
\text { Block) }\end{array}$ & $\begin{array}{l}\text { Monthly } \\
\text { (42 Block) }\end{array}$ \\
\hline location & 0.00206692 & 0.004071411 \\
$(\hat{\mu})$ & & \\
scale $(\hat{\sigma})$ & 0.00173043 & 0.002273892 \\
Shape $(\hat{\xi})$ & 0.13615331 & 0.065856103
\end{tabular}

Dari Tabel 2 didapatkan bahwa dengan jumlah blok 175 dimana setiap blok memiliki 5 pengamatan dengan estimasi parameter (location) $\hat{\mu}$ yang menyatakan letak titik pemusatan data sebesar 0.00206692, Parameter skala (scale) $\hat{\sigma}$ yang menyatakan keragaman data sebesar 0.00173043 dan Parameter ekor (shape) $\hat{\xi}$ yang menyatakan perilaku ekor kanan (maksimum) sebesar 0.13615331. Sedangkan untuk blok bulanan dengan jumlah blok 42 dimana setiap blok memiliki 5 pengamatan diperoleh estimasi parameter (location) $\hat{\mu}$ yang menyatakan letak titik pemusatan data sebesar 0.004071411, Parameter skala (scale) $\hat{\sigma}$ yang menyatakan keragaman data sebesar 0.002273892 dan Parameter ekor (shape) $\hat{\xi}$ yang menyatakan perilaku ekor kanan (maksimum) sebesar 0.065856103 .

Dari hasil estimasi parameter distribusi GEV diatas dapat dilihat bahwa estimasi parameter $\hat{\xi}$ pada harga emas yang menyatakan perilaku ekor kanan menunjukkan nilai yang lebih besar dari nol $\left(\hat{\xi}=\alpha^{-1}>0\right)$, sehingga dapat disimpulkan bahwa distribusi return berasal dari kelas distribusi Frechet dimana peluang terjadinya ekstrim lebih besar dibandingkan distribusi Gumbel ataupun Weibull. Sedangkan untuk parameter $\hat{\mu}$ (location) yang menyatakan letak titik pemusatan data didapatkan bahwa pada blok bulanan memiliki nilai yang lebih besar daripada blok mingguan, artinya estimasi parameter dengan blok bulanan memiliki probabililitas terbesar untuk terjadinya risiko pada kejadian ekstrim.

\section{Mean Excess Plot}

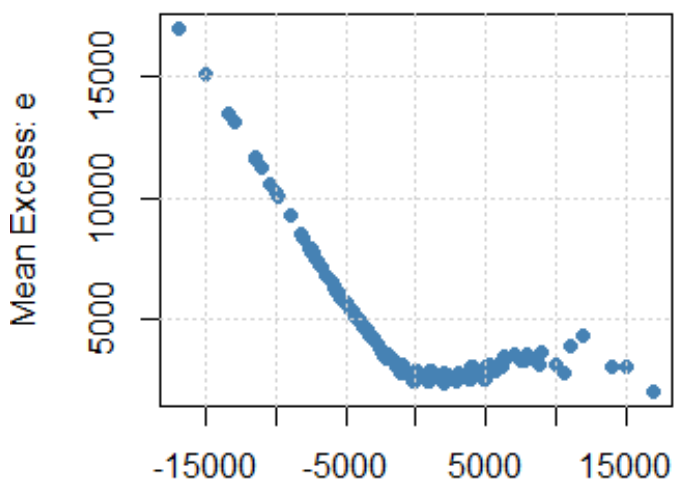

Gambar 5. Mean Excess Plot untuk data return emas 


\subsection{Menentukan Estimasi Parameter Generalized Pareto Distribution (GDP)}

Analog dengan GEV, Analisis data berupa pengujian efek GDP pada data perlu dilakukan agar pendekatan yang dilakukan dalam menentukan Value at Risk benar - benar telah menggambarkan bentuk distribusi data. Dari deskriptif diatas sudah dapat dilihat bahwa data return emas memiliki ekor gemuk (heavy tail). Cara lain akan dibuat plot Mean Excess Funtion untuk melihat heavy tail, dan hasilnya dapat dilihat pada Gambar 5. Plot MEF pada gambar 5. menunjukkan kemiringan negative, sehingga dapat dikatakan bahwa data mempunyai ekor (heavy tail).

\subsection{Menentukan threshold}

Penentuan nilai thresold didapatkan dengan metode quantil 95\%. Dimana data diurutkan dari yang terbesar sampai terkecil. Quantil $95 \%$ dari data teratas merupakan data extrim sehingga nilai thresholdpun dapat ditentukan yaitu urutan ke $\mathrm{n}+1$ dengan $\mathrm{N}$ data extrim. Nilai threshold yang diperoleh adalah 0.004864002 .

\subsection{Mengestimasi parameter bentuk dan skala menggunakan MLE}

Estimasi GPD dengan bantuan software R menghasilkan estimasi parameter yang disajikan pada Tabel 3.

\begin{tabular}{l|l}
\multicolumn{2}{|c}{ Tabel 3. Estimasi parameter GDP } \\
Karakteristik & Nilai \\
\hline $\begin{array}{l}\text { Threshold }(u) \\
\text { Banyaknya pengamatan } \\
(n)\end{array}$ & 0.004864002 \\
Banyaknya pengamatan & 876 \\
diatas threshold $(\mathrm{Nu})$ & 466 \\
Parameter skala $(\beta)$ & 0,002147 \\
Parameter bayangan $(\xi)$ & 0,60385
\end{tabular}

Tabel 3 menunjukkan bahwa banyaknya pengamatan diatas threshold $(\mathrm{Nu})$ adalah 466 pengamatan dari banyaknya pengamatan (n)sebanyak 876. Nilai threshold sebesar 0.004864002 yang menunjukkan dimulainya ekor (tail). Hasil estimasi parameter menunjukkan bahwa besarnya parameter skala sebesar $0,002147(\beta)$ dan parameter bayangan sebesar $(\xi)$ 0,60385. Setelah didapatestimasi parameter untuk GPD maka dihitung nilai VaR GPD.

\subsection{Mengestimasi VaR dengan parameter GEV dan GPD}

Hasil estimasi parameter GEV yang diperoleh pada tabel 2. selanjutnya digunakan dalam estimasi VaR untuk Harga emas. Perhitungan VaR dengan GEV menggunakan persamaan 2.7. dengan estimasi parameter pada tabel 2. dengan tingkat kepercayaan 95\% dan 99\%. Hal yang sama juga dilakukan pada hasil estimasi GDP. Perhitungan VaR dengan GDP menggunakan persamaan 2.12. dengan estimasi parameter pada Tabel 3. Hasil perhitungan VaR bisa dilihat pada Tabel 4. 
JOURNAL OF FUNDAMENTAL MATHEMATICS AND APPLICATIONS (JFMA) VOL. 2 NO. 1 (Jun 2019)

Available online at www.jfma.math.fsm.undip.ac.id

Tabel 4. perhitungan VaR dengan GEV dan GPD

\begin{tabular}{c|cc}
$\begin{array}{c}\text { Tingkat } \\
\text { kepercayaan }\end{array}$ & $\begin{array}{c}\text { VaR dengan } \\
\text { Blok } \\
\text { Mingguan }\end{array}$ & $\begin{array}{c}\text { VaR dengan } \\
\text { blok bulanan }\end{array}$ \\
\hline GEV 95\% & $-0,00008252$ & 0,004240837 \\
GEV 99\% & $-0,002184201$ & 0,000709247 \\
GPD 95\% & 0,0161337893078695 \\
GPD 99\% & 0,0404895905114821
\end{tabular}

Pemilihan Blok yang disarankan adalah blok mingguan atau 5 hari kerja karena semakin sedikit panjang blok akan memaksimumkan nilai ektrim yang ada. Selain itu berdasarkan estimasi parameter menggunakan Maximum Likelihood pada blok mingguan, didapatkan parameter shape $(\hat{\xi})>$ dari blok bulanan yang disajikan pada Tabel 4 sehingga berpeluang besar ekstrim kanan yang dapat menyebabkan kerugian lebih besar. Dari hasil perhitungan pada Tabel 4 diperoleh perhitungan nilai VaR dengan blok mingguan tingkat kepercayaan 95\% sebesar -0,00008252 artinya kerugian maksimum yang mungkin dialami investor tak lebih dari $-0,00008252$ atau $-0,008252 \%$. Misalkan investor menginvestasikan uangnya ke emas sebesar 100 juta rupiah maka kerugian maksimum yang mungkin dialami investor dalam satu hari kedepan dengan tingkat kepercayaan 95\% sebesar Rp.825.200,00. Sedangkan VaR blok mingguan dengan tingkat kepercayaan 99\%, blok Bulanan, GPD 95\% dan 99\% berturut turut adalah -0,2184\%, 0,42484\%; 0,070925\%, 1,6135\% dan 4,049\%. Dari Tabel 4 dapat dilihat juga bahwa nilai VaR pada tingkat kepercayaan 95\% kurang dari VaR dengan tingkat kepercayaan 99\% sehingga dapat disimpulkan bahwa semakin tinggi tingkat risiko yang akan diambil maka semakin besar juga tingkat konfidensi dan alokasi modal untuk menutupi kerugian yang diambil oleh investor.

\section{KESIMPULAN}

Berdasarkan hasil penelitian dapat diambil kesimpulan sebagai berikut :

1. Estimasi parameter menggunakan metode Generalized Extreme Value (GEV) pada blok yang disarankan yaitu blok mingguan dengan 3 parameter yaitu parameter (location) $\hat{\mu}$, parameter skala (scale) $\hat{\sigma}$, parameter ekor (shape) $\hat{\xi}$.

2. Pengukuran VaR dengan blok mingguan memberikan hasil bahwa nilai VaR dengan tingkat kepercayaan $95 \%$ sebesar $-0,00008252$ dan $-0,2184 \%$, untuk tingkat kepercayaan 99\%. Artinya kerugian maksimum yang mungkin dialami investor tak lebih dari 0,00008252 atau $-0,008252 \%$. Misalkan investor menginvestasikan uangnya ke emas sebesar 100 juta rupiah maka kerugian maksimum yang mungkin dialami investor dalam satu hari kedepan dengan tingkat kepercayaan 95\% sebesar Rp.825.200,00.

3. Hasil Perhitungan VaR menunjukkan bahwa nilai VaR dengan metode GPD menghasilkan VaR yang lebih tinggi dibandingkan dengan VaR dengan GEV.

4. VaR pada tingkat kepercayaan $95 \%$ kurang dari VaR dengan tingkat kepercayaan $99 \%$ sehingga dapat disimpulkan bahwa semakin tinggi tingkat risiko yang akan diambil maka semakin besar juga tingkat konfidensi dan alokasi modal untuk menutupi kerugian yang diambil oleh investor.

Setelah melakukan penelitian mengenai Value at Risk dengan metode Generalized Extreme Value dan Generalized Pareto Distribution pada harga emas, penulis menyarankan : 
1. Berdasarkan penelitian ini, diharapkan kepada investor dapat lebih selektif lagi dalam berinvestasi, terutama dalam berinvestasi saham yang memiliki kejadian - kejadian ekstrim sehingga investor tidak selalu menyiapkan dana besar untuk menutupi kerugian dalam berinvestasi.

2. Diharapkan kepada peneliti selanjutnya dapat lebih mengembangkan mengenai teori nilai ekstrim.

\section{UCAPAN TERIMAKASIH}

Penelitian ini merupakan bagian dari Hibah Penelitian Dosen Pemula (PDP) dari kemenrister Dikti Tahun anggaran 2018. Terimakasih kepada kemenristekdikti untuk hibahnya dan terimakasih kepada IST AKPRIND Yogyakarta yang telah memfasilitasi penelitian ini .

\section{DAFTAR PUSTAKA}

[1] Soleh, Muhammad., 2014, Emas Sebagai Instrumen Investasi Yang Aman Pada Saat Instrumen Investasi Keuangan Lain Mengalami Peningkatan Risiko, jurnal akuntansi Unesa, Surabaya.

[2] Gunawan, Adhitya I., Wirawati Ni Gusti P, 2013, Perbandingan Berinvestasi Antara Logam Mulia Emas Dengan Saham Perusahaan Pertambangan Emas, E-Jurnal Akuntansi Universitas Udayana 4.2:406-420, Bali.

[3] Pratiwi, Noviana., 2015, Estimasi Penyesuaian Likuiditas terhadap Value at Risk dari data historis, Jurnal Teknologi Technoscientia, Vol.8. No.1 Agustus 2015, Yogyakarta.

[4] Pratiwi, Noviana., 2014, Estimasi Penyesuaian Likuidoitas terhadap Value at Risk dengan metode Varian Kovarian, Prosiding, Seminar Nasional Aplikasi Sains \& Teknologi (SNAST) 2014, Yogyakarta.

[5] Danielsson, Jon., 2000, Value-At-Risk and Extreme Return, Tinbergen Institute and Erasmus University Rotterdam, London.

[6] Neftci, Salih N., 2000, Value at Risk Calculation, Extreme Events, and Tail Estimation, The Journal of Derivative : 1-15, Newyork.

[7] Sukono., Subanar., Rosadi, Dedi., 2008, Estimasi VaR dengan Pendekatan Extreme Value, Prosiding Semnas Matematika dan Pendidikan Matematika, Yogyakarta.

[8] Tsay, R. S., 2005, Analysis of financial time series. Second Edition. Hoboken, New Jersey : John Wiley \& Sons, Inc.

[9] Chaithep et al, 2012, Value at Risk Analysis of Gold Price Returns Using Extreme Value Theory, The Empirical Econometrics and Quantitative Economics Letters, Volume 1, Number 4, pp.151-168, Chiang Mai.

[10] Zuhara, Ummi., Akbar, M Sjahid., Haryono., 2012, Penggunaan Metode VaR dalam Analisis Risiko Investasi Saham dengan Pendekatan Generalized Pareto Distribution, Jurnal Sains dan Seni ITS Vol. 1, No. 1, Surabaya.

[11] Down, Kevin, 2002, Measuring Market Risk, John Willey \% Sons L.td. England 